DOI: https://doi.org/10.24127/ajpm.v10i4.4131

\title{
PENGEMBANGAN BUKU AJAR UNTUK MEMFASILITASI PERKULIAHAN DASAR DAN PROSES PEMBELAJARAN MATEMATIKA (DPPM)
}

\author{
Alzaber $^{1}$, Suripah $^{2 *}$, Weni Dwi Susanti ${ }^{3}$ \\ 1,2*3 Pendidikan Matematika Universitas Islam Riau, Pekanbaru, Indonesia \\ *Corresponding author. \\ E-mail: alzaber@edu.uir.ac.id ${ }^{1)}$ \\ rifah@edu.uir.ac.id ${ }^{2 *}$ \\ $\underline{\text { wenidwisusanti@student.uir.ac.id }}^{3)}$
}

Received 19 August 2021; Received in revised form 16 November 2021; Accepted 13 December 2021

\begin{abstract}
Abstrak
Penelitian ini bertujuan untuk mengembangkan buku ajar untuk memfasilitasi mahasiswa pada perkuliahan Dasar dan Proses Pembelajaran Matematika (DPPM) yang memenuhi kelayakan yakni memiliki kriteria valid dan praktis. Penelitian ini merupakan penelitian pengembangan dengan model pengembangan dari Plomp. Prosedur pengembangan terbagi menjadi tiga tahap yakni: (1) studi pendahuluan; (2) pengembangan atau pembuatan prototipe; dan (3) penilaian. Pengumpulan data menggunakan lembar angket kevalidan dan kepraktisan buku ajar. Subjek penelitian ini adalah mahasiswa calon guru program studi pendidikan matematika semester IV, dan dosen pendidikan matematika di Pekanbaru. Hasil penelitian ini menunjukkan bahwa, berdasarkan hasil dari komentar para validator buku ajar yang dikembangkan telah valid dengan kriteria baik, baik dari aspek konten, media, maupun bahasa. Selanjutnya berdasarkan ujicoba terbatas, buku ajar yang dikembangkan telah terbukti praktis dengan kategori baik. Hasil ini dapat dilihat berdasarkan masukan dan komentar beberapa mahasiswa yang menjadi subjek ujicoba bahwa, isi materi dan bahasa mudah dipahami, kalimat sederhana dan adanya ringkasan disetiap $\mathrm{BAB}$ nya sangat mendukung proses perkuliahan.
\end{abstract}

Kata kunci: Buku ajar; dasar dan proses pembelajaran matematika; pengembangan.

\begin{abstract}
This study aims to develop texbooks to facilitate students in the Basic and Mathematics Learning Process (DPPM) lectures that are feasible to use, namely meeting valid and practical criteria. This research is a development research with the development model of Plomp. The development procedure consists of three phases, namely: (1) preliminary research; (2) development or prototyping phase; and (3) assessment phase. The data collection technique used is the validity assessment sheet, and the practicality of textbooks. The research subjects were students of fourth semester mathematics education teacher candidates, and mathematics education lecturers in Pekanbaru. to produce valid and practical textbooks to facilitate the DPPM lecture process. The results of this study indicate that, based on the results of the comments of the validators, the textbooks developed have been valid with good criteria, both in terms of material, media and language aspects. Furthermore, in the limited trial stage, the developed textbooks showed practicality with good criteria. These results can be seen based on the input and comments of several students who are the subject of the test that the content of the material and language is easy to understand, simple sentences and the existence of a summary in each chapter really supports the lecture process.
\end{abstract}

Keywords: Basics and the process of learning mathematics; development; textbooks.

This is an open access article under the Creative Commons Attribution 4.0 International License

\section{PENDAHULUAN}

Pembahasan

pendidikan baik

mengenai mutu

persekolahan ataupun pada jenjang pendidikan tinggi sampai saat ini masih menjadi sorotan masyarakat. Mutu pendidikan yang dihasilkan oleh sebuah instansi pendidikan tidak terlepas dari 
kurikulum yang membingkai dan menjembatani proses pendidikan (Sanjaya et al., 2016). Pelaksanaan Pendidikan khususnya di perguruan tinggi, menjadi salah satu langkah awal untuk menyiapakan perbaikan mutu Pendidikan. Dosen sebagai salah satu pelaksana kurikulum, sarana prasarana, kebijakan, sumber pembelajaran, dan termasuk kemampuan mahasiswa perlu dijadikan pertimbangan (Mergler \& Spooner-Lane, 2012). Dosen yang memiliki dedikasi tinggi dapat mengambil peran dalam merumuskan kebijakan serta kurikulum yang mampu menghasilkan lulusan yang berkualitas (Taufikurrahman, 2018). Oleh karena hal itulah, dosen sebagai komponen dalam pendidikan memiliki kontribusi yang besar dalam menentukan kualitas pembelajaran.

Pembelajaran idealnya mampu memfasilitasi mahasiswa dalam memaknai materi, konsep dasar maupun teori yang bersifat jangka panjang. Oleh sebab itu, pembelajaran membutuhkan rancangan yang matang, sehingga mahasiswa dapat terlibat aktif di dalamnya (Suripah, 2015). Pembelajaran yang berkualitas sangat berperan dalam mendukung nilai pendidikan. Pembelajaran tidak sematamata hanya bertujuan pada pencapaian hasil belajar, akan tetapi lebih pada memaknai urgensi pembelajaran itu sendiri (Mergler \& Spooner-Lane, 2012). Seiring dengan adanya perubahan paradigma pembelajaran yang pada awalnya berpusat pada guru (teacher centered learning) ke pembembelajaran yang berpusat kepada siswa (student centered learning), metode pembelajaran pun mesti mengikuti perubahan (Bada \& Olusegun, 2015) (Rahadian, 2016), (Efendy, 2018); (Chen, 2020). Perubahan pembelajaran ini dimaksudkan untuk memperbaiki mutu pembelajaran, baik dari aspek metode ataupun paradigma mengajar dosen sebagai salah satu komponen yang mendukung proses pembelajaran. Kesuksesan sebuah pembelajaran diantaranya ditentukan oleh kesiapan dosen dalam mempersiapkan materi, metode ataupun bahan ajar sebagai penunjang perkuliahan (Kebritchi et al., 2017); Suardi, 2018).

Akan tetapi, permasalahan yang terjadi selama ini khususnya dalam jenjang pendidikan tinggi, masih minimnya dosen yang mempersiapakan pembelajaran dengan baik. Hal ini diperkuat oleh pendapat (MacKay, 2019) bahwa sebagian besar mahasiswa merasakan keresahan, kurang nyaman, dan kepentingannya terabaikan oleh penyelenggaraan pembelajaran dosen yang kurang baik. Padahal salah satu kompetensi dosen yang mesti dikuasai sebagaimana diamanahkan dalam Undang-Undang No. 14 tahun 2005 adalah dimilikinya kompetensi profesional. Banyak hal yang bisa diupayakan dalam rangka meningkatkan kompetensi professional dosen, salah satunya yaitu pengembangan bahan ajar. Kegiatan ini bertujuan untuk melakukan inovasi dalam pengembangan materi ajar terutama untuk mata kuliah program studi. Buku ajar menduduki peran yang sangat penting dalam proses pembelajaran baik bagi dosen maupun mahasiswa. Dalam proses pembelajaran mata kuliah DPPM, dosen belum menggunakan buku ajar sehingga beberapa mahasiswa kesulitan untuk memahami materi yang dijelaskan oleh dosen. Oleh karena itu, dengan adanya pengembangan buku ajar ini maka dapat digunakan dalam proses pembelajaran mata kuliah DPPM dan dapat membantu mahasiswa memahami materi dengan baik. 
DOI: https://doi.org/10.24127/ajpm.v10i4.4131

Berdasarkan hasil kajian awal
melalui pengamatan dan juga
wawancara kepada mahasiswa
pendidikan matematika di Universitas
Islam Riau, diperoleh informasi bahwa
secara umum pelaksanaan perkuliahan DPPM telah dirancang cukup baik, tetapi masih terdapat beberapa kekurangan seperti bahan materi kajian masih terlalu luas. Mahasiswa juga menyampaikan bahwa ruang lingkup materi perkuliahan DPPM merupakan konsep dasar teori keguruan yang cakupannya cukup luas, sehingga mengalami kesulitan dalam mempelajari kajian teori secara mendalam. Selain itu, konten mata kuliah DPPM perlu dibuat secara rinci dan sistematis, sehingga materi yang dipelajari terkait metode dan teori-teori belajar mudah untuk dipahami. Perkulihan perlu dikemas dalam bentuk bahan ajar yang terstruktur, dan menginspirasi mahasiswa untuk belajar lebih mudah.

Dilain pihak, beberapa penelitian sebelumnya telah mengembangkan buku ajar pada mata kuliah lain seperti trigonometri (Japa, 2012), pengantar dasar matematika (Aima \& Rahima, 2020), ataupun buku metode numerik (Purwati \& Erawati, 2021). Selain itu ada juga yang telah mengembangkan buku ajar untuk mata kuliah microteaching (Kurniawan \& Masjudin, 2018) dan evaluasi pembelajaran (Febrianto \& Puspitaningsih, 2020). Namun semua itu belum ada yang berfokus pada pengembangan buku ajar pada mata kuliah dasar-dasar dan proses pembelajaran matematika sebagai salah satu mata kuliah yang mendasari konsep dasar teori pembelajaran matematika.

Berdasarkan permasalahan yang ditemukan, memandang perlu mengembangkan sebuah produk berupa buku ajar yang mampu memfasilitasi perkulihan DPPM. Adapun tujuan dikembangkannya buku ajar ini adalah untuk mempermudah mahasiswa dalam mempelajari konsep dasar dan teori yang kemudian menjadi bekal ilmu keguruan dan profesi sebagai seorang pendidik dimasa yang akan datang. Selain itu, dosen dapat mengajak mahasiswa untuk berkolaborasi dalam pembelajaran melalui kegiatan diskusi (Bray, 2011). Keberhasilan dosen dalam mengelola pembelajaran merupakan tolak ukur kesuksesan dari sebuah proses pendidikan di perguruan tinggi. Oleh karena itu, tujuan dari penelitian ini adalah untuk mengembangkan buku ajar untuk memfasilitasi mahasiswa pada perkuliahan Dasar dan Proses Pembelajaran Matematika (DPPM) yang memenuhi kelayakan yakni memiliki kriteria valid dan praktis.

\section{METODE PENELITIAN}

Penelitian ini merupakan jenis Research and development (R\&D) menggunakan model pengembangan Plomp. Menurut (Plomp \& Nieveen, 2013) penelitian pengembangan adalah model penelitian yang terdiri atas tiga tahapan, yaitu (1) studi pendahuluan (preliminary research),

pengembangan atau pembuatan prototype (development or prototyping dan (3) penilaian (assessment phase). Pada tahap studi pendahuluan, mencakup analisis kebutuhan, identifikasi permasalahan, melakukan kajian terhadap kurikulum, dan dokumen terkait perencanaan perkuliahan. Tahap desain dan pengembangan prototipe merupakan proses mendesain dan mengembangkan prototype, melakukan evaluasi secara formatif, dan merevisi prototipe yang telah dikembangkan. Selanjutnya adalah tahap penilaian, mencakup uji coba terbatas dan ujicoba lapangan, dan 
diakhiri dengan memberikan evaluasi untuk mengambil keputusan apakah produk yang dikembangkan sudah memenuhi kriteria yang ditentukan atau belum.

Subjek penelitian ini adalah mahasiswa semester 4 pendidikan matematika universitas di Pekanbaru. Mahasiswa diminta untuk mengisi lembar angket respon terhadap buku ajar yang dikembangkan melalui angket kepraktisan. Uji coba dilaksanakan pada mahasiswa program studi pendidikan matematika yang sedang atau telah menempuh perkuliahan DPPM. Subjek penelitian diambil dengan cara acak sesuai dengan kebutuhan penelitian.

Data pada penelitian ini dikumpulkan dengan cara memberikan lembar angket validasi dan lembar kepraktisan berupa angket respon dari mahasiwa. Data penelitian yang dikumpulkan pada penelitian ini terbagi menjadi dua, yaitu data kuantitatif dan data kualitatif. Data kuantitatif didapatkan melalui penilaian validasi ahli dan praktisi, serta angket respon mahasiswa. Sedangkan data kualitatif didapatkan dari hasil review oleh validator ahli dan praktisi berupa komentar, masukkan, dan saran terkait aspek materi, media maupun bahasa pada buku ajar yang dikembangkan. Selain itu, secara kulitatif data juga didapatkan dari respon dan komentar subjek penelitian dalam hal ini adalah mahasiwa semester IV terhadap buku ajar yang dikembangkan.

Teknik analisis data untuk lembar penilian kevalidan buku ajar menggunakan angket skala Likert (1-4). Setelah penilaian didapatkan dari masing-masing validator, selanjutnya melakukan penghitungan validitas secara keseluruhan dengan cara menghitung rata-rata dari penilaian semua validator. Selanjutnya data nilai akhir yang diberikan oleh para validator ditotal dan dirata-rata kemudian dikonversi secara kualitatif kedalam skala 4 sebagaimana disajikan pada Tabel 1. Pada pengembangan buku ajar ini produk dikatakan berhasil jika memenuhi kriteria baik.

Tabel 1. Konversi data kuantitatifkualitatif skala empat

\begin{tabular}{cc}
\hline Interval & Kriteria \\
\hline$X \geq M+1.5 S$ & Sangat baik \\
\hline$M+1.5 S>X \geq M$ & Baik \\
\hline$M>X \geq M-1.5 S$ & Kurang baik \\
\hline$X<M-1.5 S$ & Sangat tidak baik \\
\hline
\end{tabular}

(Azwar, 2017)

Keterangan:

$\mathrm{M}=$ Skor mean ideal $=1 / 2$ (skor maksimum ideal+skor minium ideal)

$\mathrm{S}=$ Simpangan baku ideal $=1 / 6$ (skor maksimum ideal-skor minimum ideal)

$\mathrm{X}=$ Skor Aktual

\section{HASIL DAN PEMBAHASAN}

Produk yang dihasilkan dalam penelitian ini berupa buku ajar untuk memfasiltasi perkuliahan Dasar dan Proses Pembelajaran Matematika (DPPM). Adapun buku ajar yang dikembangkan adalah buku ajar DPPM yang layak memenuhi kevailidan dan kepraktisan. Hasil pengembangan dari buku ajar secara rinci dijelaskan sbagai berikut.

\section{Preliminary Research}

Pengembangan buku ajar terlebih dahulu diawali dengan melakukan analisis kebutuhan. Pada tahapan ini terlebih dahulu dilakukan analisis terhadap dokumen perangkat pelaksanaan perkuliahan dan dokumen kurikulum. Untuk mengetahui permasalahan yang ada, maka dilakukan wawancara terhadap mahasiswa dan dosen yang menempuh mata kuliah DPPM. Selanjutnya dilakukan evaluasi 
DOI: https://doi.org/10.24127/ajpm.v10i4.4131

dan refleksi terhadap pelaksanaan perkuliahan, serta studi dokumen terhadap RPS, dan SAP buatan dosen. Berdasarkan analisis yang dilakukan diperoleh bahwa pelaksanaan perkuliahan sudah terprogram dengan cukup baik. Akan tetapi berdasarkan perangkat yang di susun oleh dosen, materi masih banyak mengacu pada buku teks. Dosen masih mengacu pada buku referensi buatan orang lain, belum menggunakan buku ajar sendiri yang dirancang secara khusus. Dengan adanya buku ajar sendiri yang dirancang khusus, maka proses pembelajaran menjadi lebih terstruktur sesuai dengan RPS dan SAP yang telah disiapkan sebelumnya. Sistem perkuliahan masih didesain secara konvensional. Daya serap mahasiswa terhadap materi yang disampaikan belum maksimal. Hal ini disebabkan oleh banyaknya materi yang berkaitan dengan konsep dasar dan teori pembelajaran.

Temuan tersebut diperkuat oleh hasil penelitian yang telah dilakukan sebelumnya bahwa masih sedikit dosen yang menyelenggarakan perkuliahan dengan menggunakan buku ajar buatan sendiri (Sugiyono et al., 2011; Setyowati et al., 2014). Berdasarkan hasil wawancara terhadap perwakilan 6 orang mahasiswa diperoleh informasi bahwa salah satu kesulitan dalam perkuliahan DPPM yang diselenggarakan oleh dosen adalah kesulitan mencari referensi untuk digunakan selama proses perkuliahan. Referensi yang digunakan lebih banyak bersumber dari internet ataupun referensi lain yang bersifat umum sehingga sulit dipahami oleh mahasiswa. Hal ini disebabkan kebanyakan dosen menggunakan bahan atau referensi yang dibuat oleh orang lain maupun bahan yang diperoleh secara gratis dari internet. Selain itu, selama proses pembelajaran daring dosen tidak dapat memberikan bahan ajar berupa hardcopy yang bisa langsung dibaca oleh mahasiswa. Dari hasil wawancara tersebut, mahasiswa merasa membutuhkan buku ajar yang terstruktur sehingga memuat materimateri yang sudah ada dalam RPS dan SAP dosen. Oleh karena itu, mahasiswa merasa membutuhkan kehadiran sebuah buku ajar yang memang dibuat oleh dosen yang memuat materi-materi yang disajikan dalam RPS selama satu semester. Dengan demikian, dapat diambil kesimpulan bahwa diperlukan buku ajar yang mengemas materi secara terstruktur sesuai kebutuhan capaian pembelajaran untuk memfasilitasi mahasiwa dalam perkuliahan.

Langkah selanjutnya dalam analisis studi pendahuluan ini adalah analisis terhadap kajian materi. Pada langkah ini akan dirinci Capaian Pembelajaran (CPL) pada mata kuliah DPPM dengan merujuk pada kurikulum yang digunakan. Kemudian cakupan materi akan disesuaikan dengan capaian pembelajaran pada satuan acara perkuliahan (SAP) yang kemudian digunakan untuk merancang dan mengembangkan materi pada buku Ajar DPPM pada fase desaindan pengembangan prototipe.

\section{Development or prototyping phase}

Fase pengembangan prototipe diawali dengan menentukan tujuan pembelajaran secara khusus berdasarkan capaian pembelajaran dan cakupan materi yang disesuaikan dengan RPS dan SAP, menentukan subjek uji coba, serta desain produk yang akan dikembangkan. Berdasarkan tujuan yang akan dicapai, selanjutnya dirancang materi, sesuai dengan kebutuan capaian pembelajaran yang terbagi sebanyak enam Bab. Masing- 
masing bagian disertai dengan teori pendahuluan secara garis besar dari berbagai rujukan, baik dari buku referensi maupun jurnal-jurnal yang relevan, aplikasi, ringkasan, latihan soal, dan daftar rujukan. Selanjutnya pada bagian akhir, disertai dengan glosarium dan indeks. Hasil dari perancangan dan pengembangan ini berupa buku ajar untuk memfasilitasi perkuliahan DPPM. Draft hasil dari tahap ini selanjutnya disebut sebagai prototipe 1 yang siap divalidasikan kepada para validator baik secara konten materi, bahasa, maupun media.

Validasi terhadap buku ajar dilakukan pada fase desain dan pengembangan prototipe awal melalui beberapa tahapan. Data terkait kevalidan produk yang dikembangkan diperoleh dari tiga validator untuk memberikan penilaian terhadap kualitas dan kelayakan terhadap buku ajar. Validator ahli merupakan dosen dan praktisi pendidikan dari Universitas Riau, Universitas PGRI Yogyakarta, dan Universitas Islam Riau. Validasi dilakukan mulai pada tanggal 6 Januari 2021 sampai dengan Awal Maret 2021. Hasil validasi dari ketiga validator ahli terhadap produk yang dikembangkan diperoleh skor rata-rata adalah 127 dengan kriteria baik. Hasil secara keseluruhan disajikan pada Tabel 2 .

Tabel 2. Hasil validasi buku ajar kriteria aspek materi, bahasa dan media.

\begin{tabular}{lllllll}
\hline \multirow{2}{*}{ Validator } & \multicolumn{2}{c}{ Aspek Materi } & \multicolumn{2}{c}{ Aspek Bahasa } & \multicolumn{2}{c}{ Aspek Media } \\
\cline { 2 - 7 } & \multicolumn{1}{c}{ Skor } & Kriteria & Skor & Kriteria & Skor & Kriteria \\
\hline Validator_1 & 49 & Sangat baik & 32 & Baik & 48 & Baik \\
Validator_2 & 47 & Baik & 29 & Baik & 47 & Baik \\
Validator_3 & 50 & Sangat baik & 30 & Baik & 49 & Sangat baik \\
Jumlah & 146 & & 91 & & 144 & \\
Rata-rata & 48,67 & Baik & 30,33 & Baik & 48 & Baik \\
\hline Rata-rata keseluruhan & & & $\mathbf{1 2 7}$ & & & Baik \\
\hline
\end{tabular}

Hasil penilaian dari para validator terhadap buku ajar pada Tabel 2 menunjukkan bahwa produk yang dikembangkan untuk setiap aspeknya berada pada kriteria "baik". Dengan demikian, buku ajar DPPM yang dikembangkan telah memenuhi kevalidan dan kepraktisan untuk dapat digunakan dengan revisi kecil. Oleh karena itu, masih terdapat beberapa bagian yang perlu diperbaiki baik dari aspek, konten materi, media maupun bahasa.

Beberapa bagian yang diperbaiki berdasarkan masukkan dan saran dari validator pada saat validasi diantaranya pada bagian Materi, Bab 2 point 6 bagian contoh penerapan teori Guilford dalam pembelajaran matematika dan bagian ringkasan. Teori Guilford adalah salah satu teori belajar yang mengenalkan kreativitas berpikir terkait pengenalan pada bilangan, menggambar bangun datar dan bangun ruang. Revisi yang lain adalah pada desain dan layout, pemisahan antar paragraph supaya lebih jelas. Selanjutnya masukan juga diberikan pada aspek tata tulis dan bahasa. Bahasa asing yang diserap kedalam bahasa Indonesia kurang sesuai, dan beberapa kalimat terlalu panjang sehingga kurang efektif. Salah satu cuplikan materi pada prototipe 1 disajikan pada Gambar 1. 
DOI: https://doi.org/10.24127/ajpm.v10i4.4131

Siswa di kelas diperkenalkan sebuah bangun ruang, yaitu kubus ABCD EFGH yang disusun dari beberapa bidang sisi, siswa di kelas diperkenalkan salah satu jaring-jaring kubus sebagai berikut. Siswa diberikan waktu untuk memikirkan berdasarkan contoh yang telah diberikan untuk menemukan sendiri susunan jaringjaring kubus yang lain.
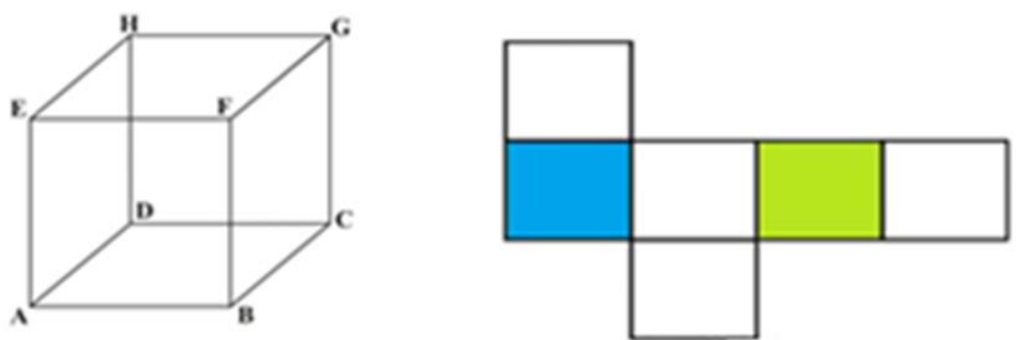

Gambar 1. Salah Satu Cuplikan Materi Pada Prototipe 1.

Setelah proses validasi, pada bagian materi Teori Guliford diperbaiki dengan memperhatikan masukan dan saran supaya memasukkan unsur teknologi terkait materi Teori Guilford pada bangun ruang tersebut. Lalu ditambahkan pengenalan software salah satunya adalah Geogebra yang bisa digunakan untuk menyajikan gambar bangun ruang kubus, mulai dari bentuk utuh dan jaring-jaringnya. Kalimat pada pengantar gambar dikemas dengan bahasa yang komunikatif dan tampilan gambar bangun ruang kubus lengkap dengan unsur-unsurnya pada sintaks aplikasi software yang digunakan. Hasil revisi disajikan pada Gambar 2.

Siswa di kelas diperkenalkan sebuah bangun ruang, yaitu kubus ABCD EFGH yang disusun dari beberapa bidang sisi, siswa di kelas diperkenalkan salah satu jaring-jaring kubus sebagai. berikut. Siswa diberikan waktu untuk memikirkan berdasarkan contoh yang telah diberikan untuk menemukan sendiri susunan jaring-jaring kubus yang lain. Rada proses pembelajaran guru dapat menggunakan aplikasi Geogebra seperti Gambar berikut.

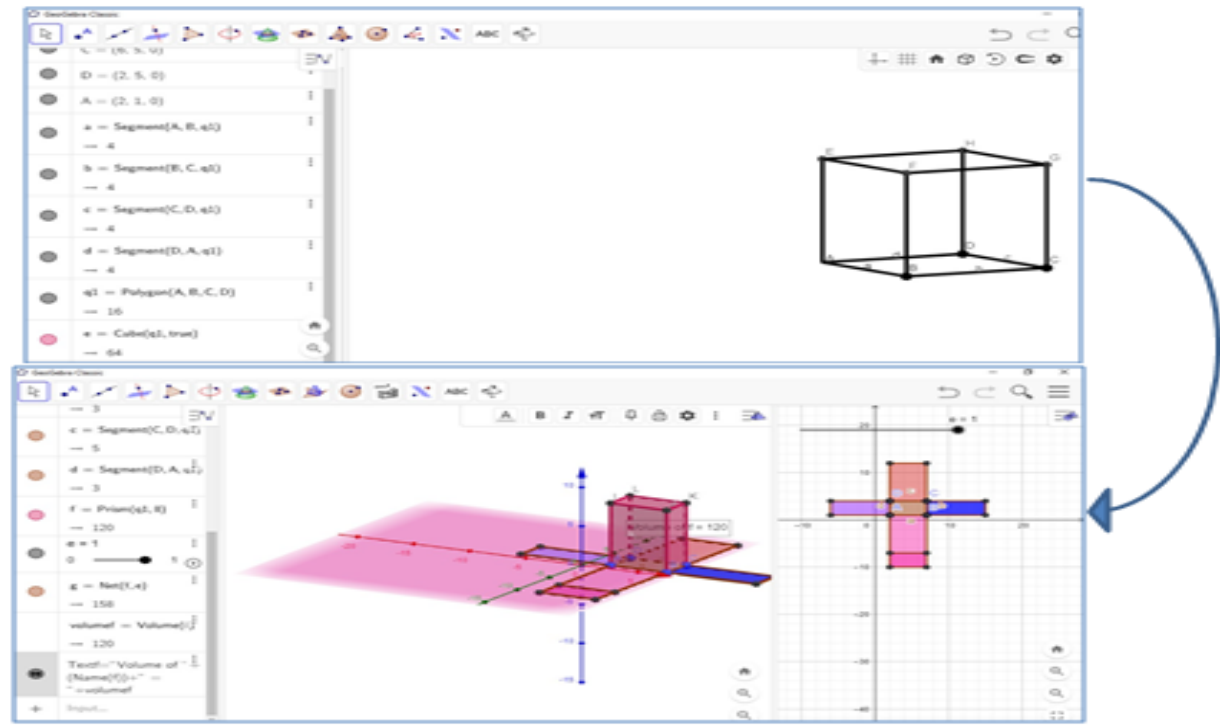

Gambar 2. Hasil Revisi Materi Pada Prototipe 1. 
DOI: https://doi.org/10.24127/ajpm.v10i4.4131

Bagian ringkasan pada setiap Bab nya bertujuan untuk mempermudah mahasiwa dalam memahami materi yang disajikan. Mahasiswa tidak harus membaca isi materi secara detail, sehingga memudahkan dalam belajar. Proses validasi, pada bagian ini dilakukan perbaikan pada tampilan ringkasan dalam bentuk paragraph, yang sebelumnya diatur dalam bentuk pointer. Selain itu, beberapa kesalahan terkait aspek bahasa seperti kalimat yang tidak efektif karena terlalu panjang juga dilakukan perbaikan pada setiap Bab nya. Penulisan dan alih bahasa asing juga diperbaiki sesuai masukkan dan saran yang diberikan oleh validator.

Bagian terakhir adalah desain dan tata letak, baik gambar maupun tulisan masih kurang jelas batas pemisah antar paragraph. Batas antar paragraph bertujuan untuk memisahkan antar bagian paragraph yang satu dengan paragraph yang lain, bisa juga berfungsi untuk memperjelas batas antar pembahasan pada sub-bagian tertentu. Perbaikan yang dilkukan pada bagian ini dengan memberikan sub bagian berupa penomoran dan menebalkan tulisan (Bold) pada sub-sub bagian pada setiap Bab pembahasan.

Secara keseluruhan hasil perbaikan terhadap prototipe 1 yang dikembangkan selanjutnya di sebut sebagai prototipe 2 . Berakhirnya proses pada tahapan ini, prototipe 2 yang dihasilkan, berdasarkan hasil revisi, masukkan dan saran pada tahap validasi secara kualitatif dapat dinyatakan valid. Berdasarkan hasil penilaian pada Tabel 2, secara kuantitatif, juga dapat dinyatakan valid. Prototipe 2 yang telah dihasilkan, selanjutnya diujicobakan pada tahap Assesment phase.

\section{Assesment Phase.}

Pada tahap asesmen dilakukan uji coba pada prototipe 2 untuk mengetahui kepraktisan dan keefektifan pengembangan buku ajar. Pada tahap ini, ujicoba produk yang dikembangkan terbagi atas dua tahapan yaitu uji coba terbatas dan uji coba secara luas. Namun demikian, pada tahap ini baru sampai pada tahap uji coba terbatas dikarenakan pembelajaran dimasa pandemi ini yang kurang efektif untuk menyelenggarakan ujicoba luas secara langsung. Uji coba terbatas dilakukan dengan memberikan buku ajar kepada 13 mahasiswa. Adapun tujuan uji coba terbatas ini adalah untuk melihat keterbacaan produk yang dikembangkan dalam lingkup terbatas sejauh mana respon mahasiwa terhadap kepraktisan pengembangan buku ajar. Selanjutnya diberikan angket respon untuk melihat keterbacaan seluruh komponen buku yang dikembangkan dan meminta mahasiswa untuk memberikan respon. Respon dari mahasiswa terhadap buku yang dikembangkan disajikan pada Tabel 3.

Tabel 3. Respon mahasiswa terhadap buku ajar.

\begin{tabular}{ccc}
\hline Responden & Penilaian & Kriteria \\
\hline MT1 & 49 & Sangat Baik \\
MT2 & 48 & Baik \\
MT3 & 47 & Baik \\
MT4 & 46 & Baik \\
MT5 & 44 & Baik \\
MT6 & 43 & Baik \\
MT7 & 43 & Baik \\
MT8 & 46 & Baik \\
MT9 & 50 & Sangat baik \\
MT10 & 47 & Baik \\
MT11 & 46 & Baik \\
MT12 & 49 & Sangat baik \\
MT13 & 48 & Baik \\
Jumlah & 606 & Baik \\
Rata-rata & 46,61 & Mainasi
\end{tabular}


DOI: https://doi.org/10.24127/ajpm.v10i4.4131

Berdasarkan Tabel 3, tampak bahwa tiga dari tiga belas mahasiswa memberi penilaian dengan kriteria sangat baik secara kualitatif dan sepuluh orang lainnya memberikan penilaian dengan kriteria baik. Namun demikian, secara keseluruhan dari ketiga belas mahasiwa diperoleh rerata skor penilaian 46,61. Berdasarkan skor penilaian yang diberikan tersebut, disimpulkan bahwa produk pengembangan buku ajar telah memenuhi kepraktisan dengan kriteria "Baik". Dari 13 mahasiswa yang dijadikan responden, telah memberi penilaian secara positif terhadap buku ajar yang dikembangkan.

Selain berdasarkan pada kriteria kepraktisan, juga dapat dilihat berdasarkan masukan dan saran dari subjek ujicoba sebagai bahan untuk memperbaiki prototipe 2 sebelum diujicobakan secara luas. Komentar berupa saran dan masukan yang diberikan oleh mahasiswa dirangkum pada Tabel 4.

Tabel 4. Saran dan masukan mahasiswa ujicoba terbatas

\begin{tabular}{cl}
\hline No & Komentar, saran dan masukan \\
\hline 1 & $\begin{array}{l}\text { Materi mudah di pahami, sudah ada } \\
\text { soal latihan, jadi punya gambaran } \\
\text { yang jelas. }\end{array}$ \\
2 & $\begin{array}{l}\text { Sajian materi tertentu masih cukup } \\
\text { luas, mungkin bisa lebih disimpelkan } \\
\text { lagi. }\end{array}$ \\
3 & $\begin{array}{l}\text { Ada rangkumanya, jadi lebih mudah } \\
\text { memahami materinya. }\end{array}$ \\
4 & $\begin{array}{l}\text { Beberapa kalimat masih terlalu } \\
\text { panjang. }\end{array}$ \\
5 & $\begin{array}{l}\text { Masih ada beberapa bahasa asing } \\
\text { yang saya kurang paham Ibu. }\end{array}$ \\
6 & $\begin{array}{l}\text { Perlu ditambah lagi aplikasi } \\
\text { penggunaan teknologi dan software } \\
\text { pada penerapan model, maupun } \\
\text { metode pada pembelajaran. }\end{array}$ \\
\hline
\end{tabular}

Berdasarkan masukan dan saran dari mahasiswa, dilakukan perbaikan pada produk buku ajar secara signifikan terhadap prototipe 2. Cakupan materi termasuk pendahuluan dan konsep dasar yang masih terlalu luas direvisi menjadi lebih sederhana. Beberapa kalimat yang masih terlalu panjang lebih dibuat simpel sehingga tidak banyak lagi mengandung anak kalimat. Selain itu, beberapa bahasa asing yang diserap kedalam bahasa juga dijelaskan dalam glosarium. Selain terkait pada aspek materi dan bahasa, setelah tahapan ini, juga dilakukan perbaikan terhadap aplikasi teknologi pada buku ajar terkait dengan alikasi materi pada Model maupun metode pembelajran yang digunakan dalam bentuk contoh perangkat pembelajaran dengan model atau metode tertentu.

Memperhatikan komentar dari mahasiswa uji coba berupa saran dan masukan pada tahap assesment phase ini, maka dilakukan revisi dengan menyederhanakan materi untuk Bab 2 serta menambahkan glosarium terkait bahasa asing dan aplikasi model ataupun metode dan pendekatan pembelajaran pada contoh lampiran RPP. Revisi yang telah dilakukan pada prototipe 2, setelah melalui assessment phase, selanjutnya disebut sebgai prototipe 3. Prototipe 3 yang dihasilkan secara kualitatif dapat dikatakan telah memenuhi kriteria valid dan praktis berdasarkan masukan dan saran yang diberikan. Secara kuantitaif, buku ajar yang dikembangkan ditentukan dengan cara menghitung skor angket respon mahasiswa. Dari hasil analisis diperoleh skor pada kategori "Baik"(dapat dilihat pada Tabel 3).

Setelah prototipe 3 ini dihasilkan, seharusnya dilanjutkan dengan ujicoba secara luas ke lapangan untuk mengetahui keefektifan dari produk buku ajar yang dikembangkan. Namun demikian dengan kondisi pembelajaran 
yang dilakukan secara daring ini, peneliti baru sampai pada tahapan valid dan praktis. Oleh karena itu, pada tahapan assessment phase ini, ujicoba secara luas belum dapat dilanjutkan.

Lebih lanjut, hasil penelitian yang telah dideskripsikan berdasarkan tahaptahap pengembangan Plomp, dilakukan pembahasan secara menyeluruh sebagai berikut. Pada tahap studi pendahuluan, dilakukan analisis terkait dokumen kurikulum, konten materi dan karakteristik mahasiwa terhadap kebutuhan perkuliahan. Berdasarkan wawancara terhadap mahasiswa dan dosen yang menempuh mata kuliah DPPM serta studi dokumen perangkat digunakan pada perkuliahan diperoleh hasil bahwa materi masih banyak mengacu pada buku teks buatan orang lain, belum menggunakan buku ajar sendiri yang dirancang secara khusus. Daya serap mahasiswa terhadap materi yang disampaikan belum maksimal. Hal ini disebabkan oleh banyaknya materi yang berkaitan dengan konsep dasar dan teori pembelajaran. Hal ini sejalan dengan penelitian yang dilakukan oleh MacKay (2019), Putri \& Damayanti (2019), serta Riyanto \& Nugrahanti (2018) yang menyatakan bahwa sebagian besar mahasiswa merasa kurang nyaman dalam pelaksanaan proses pembelajaran dikarenakan kurang memahami materi yang dijelaskan oleh dosen. Oleh karena itu dibutuhkan buku ajar buatan dosen sendiri untuk memfasilitasi perkuliahan. Hasil ini dijadikan sebagai konsep dasar untuk merancang dan mengembangkan materi pada buku Ajar DPPM yang dikembangkan.

Pada development or prototyping phase, kajian awal yang dilakukan dianalisis untuk merancang materi, sesuai dengan kebutuan capaian pembelajaran yang terbagi sebanyak enam Bab. Hasil tahap ini berupa buku ajar untuk memfasilitasi perkuliahan DPPM. Draft hasil dari tahap ini selanjutnya disebut sebagai prototipe 1 . Selanjutnya draft buku ajar pada prototipe 1 divalidasikan pada 3 orang ahli baik dari aspek materi, media maupun bahasa. Berdasarkan hasil validasi para ahli tersebut, buku ajar Hasil penilaian dari ketiga validator ahli, buku ajar yang dikembangkan dikatakan valid dengan kriteria "baik" dari aspek materi, media, maupun bahasa. Namun terdapat sedikit perbaikan yakni mengintegrasikan teknologi untuk gambar bangun ruang pada materi Teori Guilford. Pengintegrasian teknologi pada materi pelajaran kini dianggap penting dan tidak boleh diabaikan oleh pendidik, hal ini dikarenakan teknologi memiliki peranan penting salah satunya untuk meningkatkan minat siswa dalam proses pembelajaran (Gloria, 2016; Harsa, 2021; Pratama et al., 2019)

Kemudian pengembangan ini menghasilkan prototipe 2. Setelah buku ajar pada prototipe 2 dinyatakan valid, dilanjutkan dengan assessment phase yaitu menguji kepraktisan melalui respon mahasiwa pada skala terbatas. Adapun aspek penilaian untuk kepraktisan dinilai dengan memberikan angket respon kepada mahasiwa baik dari aspek materi, bahasa, dan ketertarikan terhadap buku ajar yang dikembangkan. Pada tahap ini 13 orang mahasiswa semester 6 menjadi dengan kemampuan kognitif heterogen diberikan angket respon. Pada tahap ini, mahasiswa dapat memahami materi yang disajikan. Mahasiswa juga dapat memahami isi buku dengan mudah karena sudah ada rangkuman pada setiap Bab nya. Hasil dari validasi berupa saran dan masukan pada tahapan ini dijadikan dasar untuk memperbaiki 
prototipe 2. Selanjutnya hasil revisi berdasarkan saran dan masukan pada prototipe 2 kemudian menghasilkan prototipe 3 yang telah teruji kevalidan dan kepraktisanya dengan kriteria kepraktisan "Baik". Selanjutnya prototipe 3 yang telah memenuhi kriteria yang disyaratkan akan diujicobakan secara luas agar dapat diketahui keefektifan dari produk yang dikembangkan. Adapun implikasi hasil pengembangan buku ajar ini adalah dapat digunakan oleh dosen untuk memfasilitasi perkuliahan. Selain itu, mahsiswa menjadi lebih mudah dalam memahami materi perkuliahan yang disajikan.

\section{KESIMPULAN DAN SARAN}

Hasil penelitian menunjukkan bahwa Buku ajar DPPM yang dikembangkan telah memenuhi kriteria valid dengan kriteria "Baik" dari aspek materi, media maupun bahasa berdasarkan penilaian dan komentar dari validsi ahli pada tahap perancangan dan pengembangan prototipe. Selanjutnya pada tahap asesmen dilakukan ujicoba terbatas terhadap pengembangan buku ajar dengan melibatkan 13 mahasiswa Semester IV Pendidikan Matematika Universitas Islam Riau. Hasil Uji coba terbatas menunjukkan bahwa pengembangan buku ajar telah memenuhi kepraktisan dengan kriteria baik.

\section{DAFTAR PUSTAKA}

Aima, Z., \& Rahima, R. (2020). Pengembangan Buku Kerja Pengantar Dasar Matematika Berbasis Konstruktivisme. Journal of Medives: Journal of Mathematics Education IKIP Veteran Semarang, 4(1), 161171.
Azwar, S. (2017). Metode penelitian psikologi. In Yogyakarta: Pustaka Pelajar.

Bada, S. O., \& Olusegun, S. (2015). Constructivism learning theory: A paradigm for teaching and learning. Journal of Research \& Method in Education, 5(6), 66-70.

Bray, W. S. (2011). A Collective Case Study of the Influence of Teachers , Beliefs and Knowledge on Error-Handling Practices During Class Discussion of Mathematics. 42(1), 2-38.

Chen, C. (2020). Education Paradigm: from Factory Models of Schools to the Future.

Efendy, R. (2018). Rekonstruksi Makna Belajar dalam Upaya Merespon Perubahan Paradigma Pembelajaran Era Milenial. AlIshlah: Jurnal Pendidikan Islam, 16(1), 37-61.

Febrianto, R., \& Puspitaningsih, F. (2020). Pengembangan Buku Ajar Evaluasi Pembelajaran. Education Journal: Journal Educational Research and Development, 4(1), 1-18.

Gloria, R. Y. (2016). Meningkatkan Minat Ipa Melalui Implementasi Integrasi-Interkoneksi Keislaman di Lingkungan Pondok Pesantren Al- Anwariyah Tegal Gubug Kabupaten Cirebon. Phenomenon: Jurnal Pendidikan Mipa, 6(1), 57-68.

Harsa, F. S. (2021). Integritas ICT dalam Pembelajaran Matematika. Jurnal Paedagogi, 48(2), 39-62. www.ine.es

Japa, I. G. N. (2012). Pengembangan Buku Ajar Berpendekatan Pendidikan Matematika Realistik dan Pemecahan Masalah Terbuka. Jurnal Pendidikan Dan Pengajaran, 45(2). 
Kebritchi, M., Lipschuetz, A., \& Santiague, L. (2017). Issues and challenges for teaching successful online courses in higher education: A literature review. Journal of Educational Technology Systems, 46(1), 4-29.

Kurniawan, A., \& Masjudin, M. (2018). Pengembangan buku ajar microteaching berbasis praktik untuk meningkatkan keterampilan mengajar calon guru. Prosiding Seminar Nasional Pendidik Dan Pengembang Pendidikan Indonesia, 9-16.

MacKay, J. R. D. (2019). Show and 'tool': How lecture recording transforms staff and student perspectives on lectures in higher education. Computers \& Education, 140, 103593.

Mergler, A. G., \& Spooner-Lane, R. (2012). What pre-service teachers need to know to be effective at values-based education. Australian Journal of Teacher Education, 37(8), 66-81. https://doi.org/10.14221/ajte.2012 v37n8.5

Plomp, T. (SLO), \& Nieveen, N. (SLO). (2013). Educational Design Research Educational Design Research. Educational Design Research, 1-206.

Pratama, A. P., Kharisma, A. P., \& Wihandika, R. C. (2019). Pengembangan Aplikasi Daily Quest: Aplikasi Untuk Menangani Kemalasan Pada Anak Menggunakan Platform Android. Jurnal Pengembangan Teknologi Informasi Dan Ilmu Komputer EISSN, 3(10), 964X.

Purwati, N. K. R., \& Erawati, N. K. (2021). Pengembangan Buku Ajar Metode Numerik Berbasis Pembelajaran Kolaboratif.
Mosharafa: Jurnal Pendidikan Matematika, 10(1), 37-48.

Putri, K. E., \& Damayanti, S. (2019). Pengembangan E-Learning Menggunakan Portal Pembelajaran Mahasiswa pada Mata Kuliah Konsep Dasar IPA 2 di Era Disruption. Jurnal Pendidikan Dasar Nusantara, 5(1), 117-132.

Rahadian, D. (2016). Pergeseran Paradigma Pembelajaran pada Pendidikan Tinggi. Jurnal Petik, 2(1), 1-7.

Riyanto, S., \& Nugrahanti, F. (2018). Pengembangan Pembelajaran Statistika Berbasis Praktikum Aplikasi Software SPSS dengan Bantuan Multimedia untuk Mempermudah Pemahaman Mahasiswa terhadap Ilmu Statistika. DoubleClick: Journal of Computer and Information Technology, 1(2), 62. https://doi.org/10.25273/doublecli ck.v1i2.1590

Sanjaya, W., Darmawan, D., \& Supriadie, D. (2016). Pengembangan Perangkat Kurikulum dan Rancangan Pembelajaran. PEDAGOGIA, 12(2), 126-135.

Setyowati, R. D., Albab, I. U., \& Tsalatsa, A. N. (2014). Pengembangan Bahan Ajar Dengan ScientificApproach Melalui Mobile Learning System Mata Kuliah Aljabar. AKSIOMA: Jurnal Matematika Dan Pendidikan Matematika, 5(2/septembe).

Suardi, M. (2018). Belajar \& pembelajaran. Deepublish.

Sugiyono, S., Nuryanto, A., \& Mulyatiningsih, E. (2011). Dampak Penerapan SMM ISO 9001: 2000 Terhadap Kualitas 
DOI: https://doi.org/10.24127/ajpm.v10i4.4131

Layanan Akademik Dan Lulusan FT UNY. Jurnal Pendidikan Teknologi Dan Kejuruan, 20(2).

Suripah, M. (2015). Tipe Student Teams Achievement Divisions (STAD) Dan Tipe Think-Pair-Share (TPS) Pada Siswa Smp. Jurnal Pengajaran Matematika Dan Ilmu Pengetahuan Alam, 20(2), 125132.

https://doi.org/10.18269/jpmipa.v 20i2.575

Taufikurrahman, R. (2018). Dosen dan Pengembangan Bahan Ajar. NUANSA: Jurnal Penelitian Ilmu Sosial Dan Keagamaan Islam, 15(1), 223-250. 